Article Type: Research Paper

\title{
Estimation of Willingness to Pay for Development and Preservation of Liwa Botanical Garden Indonesia
}

\author{
Sundari Anda Arista $^{1}$ and Endah Saptutyningsih ${ }^{2 *}$
}

\begin{abstract}
This research aims to find out how big the willingness of Kebun Raya Liwa visitors to pay for the ticket and to find the factors influencing that willingness. Visitors of Kebun Raya Liwa who are 20 years old or above are the subject of this report. This study uses primary data and uses a purposive sampling method to interview the subject with 304 people. The instrument used for the analysis is the Contingent Valuation Method (CVM). Each person is Rp 6.500 according to the average results of willingness to pay using Dichotomous Choice. Results of the analysis show that variables in age, education and income positively affect the willingness to pay. The perception of the visitors negatively affects the willingness to pay. While distance and frequency of visits do not affect the payment will.
\end{abstract}

\begin{abstract}
AFFILIATION:
1,2 Department of Economics, Faculty of Economics and Business, Universitas Muhammadiyah Yogyakarta, Yogyakarta, Indonesia

*CORRESPONDENCE:

endahsaptuty@umy.ac.id
\end{abstract}

THIS ARTICLE IS AVALILABLE IN:

http://journal.umy.ac.id/index.php/jerss

DOI: 10.18196/jerss.v4i2.10103

\section{CITATION:}

Arista, S.A. \& Saptutyningsih, E. (2020). Estimation of willingness to pay for development and preservation of Liwa Botanical Garden Indonesia. Journal of Economics Research and Social Sciences, 4(2), 118-128
Keywords: Willingness to Pay (WTP); Contigent Valuation Method; economic valuation; tourism; preservation

\section{Introduction}

Tourism can be interpreted as a journey while someone strives to find balance and happiness with the environment and the social, cultural, natural and political dimensions (Spillane, 1991). Indonesia is a very interesting country to visit because it possesses natural potential, flora and fauna, thick traditions, different languages in each region and respect for their respective religions.

Every region in Indonesia has different cultural and historical diversity which has a particular tourist attraction. In the past, regional culture can be seen from any relics in the area such as traditional houses, dances, traditional clothes and traditional events that the community often performs routinely. With increasing knowledge of the benefits of tourism at this time, the government has begun to move and become aware of the existence of the tourism sector, which can provide long-term benefits if the government can manage and maintain the tourism sector well by raising awareness of the importance of conservation in the tourism sector. And with the regional autonomy policy that gives local governments authority to enhance the wellbeing of their people through the management of established natural resources. 
People can increase their income in areas where tourists visit by selling goods and services, such as opening restaurants, building lodging, selling souvenirs, and renting out the facilities needed. Tourism industry can create jobs to help these attractions develop. The benefit is that it can reduce the rate of unemployment rate in the area and can increase the regional original income (PAD) obtained from taxes, accommodation and retribution. Each region in Indonesia has its own natural beauty attractions, one of which is in Lampung Province. Tourist visitors in the province of Lampung continue to see a significant increase in the number of tourists reaching 11.641.199 in 2017. Most visitors originate from within the country. Tourist arrivals in Lampung, both foreign and domestic tourists, are rising every year (Lampung Province in Figures, 2018). West Lampung Regency has a high tourist attraction because it is identical with natural tourism which is still original there are many mountains and hills. The Liwa Botanical Garden is a new tourist spot in Lampung, right in West Lampung which attracts the attention of many local people. The Liwa Botanical Garden is located in Pekon Kubu Perahu, Balik Bukit District, West Lampung Regency. The Liwa Botanical Garden is bordered by Kubu Perahu Resort Balik Bukit ecotourism, Bukit Barisan Selatan National Park (TNBBS), and tourist attraction in the form of a waterfall TNBBS has been designated by UNESCO as a World Tourist of the Tropical Forests of Sumatra (Tropical Rainforest Heritage of Sumatera in 2004). From Bandar Lampung, the Liwa Botanical Garden is $\pm 296 \mathrm{~km}, \pm 6$ hours' drive from the provincial capital. From Pesisir Barat Regency to the city of Liwa as far as $\pm 38 \mathrm{~km}$ which can be taken $45-60$ minutes of travel, which is the West Coastal Regency located in the West of Liwa City, West Lampung. As the number of visitors grows it will affect the environment if visitors do not realize the importance of preserving the environment. In order to preserve the tourist attraction, the nature and climate around the Liwa Botanical Garden will need to be enhanced, which definitely needs funding. In this case the community should be involved in protecting the environment around the tourist attraction especially for Liwa Botanical Garden visitors. Hence, the amount of willingness to pay visitors to Liwa Botanical Garden needs to be known so that the management of Liwa Botanical Garden attractions can be even better managed in the future.

\section{Literature Review and Hypotheses Development}

When it comes to estimate how much willingness to pay (WTP) visitors to develop quality and environmental sustainability in Liwa Botanic Garden attractions, an approach using the Contingent Valuation Method (CVM) is a survey method used to ask respondents about the value they want to give to commodities that do not have a market such as environmental goods (Yakin, 1997). While the purpose of CVM is to find out willingness to pay from the community (Fauzi, 2010). The CVM approach is used because it can (1) measure individuals ' willingness to pay (WTP) against changes in the price hypothesis of tourism activities; (2) evaluate trips to multiple destinations; (3) evaluate the pleasure of using these services in the region, both users and non-users; (4) evaluate goods that are priced too small. (Mitchell \& Carson, 1989; Lee et al., 1998). 
A number of previous studies have examined similar issues relating to the economic valuation of attractions which are then used as a reference in this study. Research conducted by Saptutyningsih and Selviana (2017) on the valuation of ecotourism in Ciamis, West Java by using the Travel Cost Method (TCM) and Contingent Valuation Method (CVM), found that income and education factors influence visitor willingness to pay. Another study of willingness to pay and travel costs for making maps of the economic value zones of the Marina Beach and Puri Maerokoco Semarang areas using Geographic Information Systems (GIS) with TCM, VCM, and WTP approaches, the results are income, interests and conversions affecting CVM, old visiting effect on TCM (Putri, Subiyanto, \& Awaludin, 2017).

Gaviria and Martínez (2014) conducted a study related to air pollution and WTP of individuals exposed in Columbia, resulting in the conclusion that age, income, symptoms of disease, and pollution exposure had a positive effect on willingness to pay. Similar research on the ramsar site in Morocco uses the Travel Cost Method and the Contingent Valuation Method. Based on the results of contingent valuation, the variable level of income, number of dependents of children, visitor satisfaction and time of visit significantly influence the amount of willingness to pay Ramsar Site visitors. Willingness to pay turns out to have a good correlation with some socio-economic variables of visitors. Visitors with higher incomes and satisfied with their visit are willing to pay more (Mohammed, Abedellatif, \& Faiccedil, 2013). The average WTP for environmental services in the study area across the socioeconomic strata show different results between men and women. This is because the benefits obtained differ depending on access to different forest uses. Marital status shows that those who are married have higher WTP rates than those who are not married. High income also has the effect of a high average WTP per month. Respondents with higher education indicate that formal education can increase a person's willingness to pay to contribute to environmental ecosystem services in the forest (Adekunle, 2012).

Yu, Jin, and Du (2018) conducted research on the effect of Willingness to Pay for marine conservation conducted in China using the Countingent Valuation Method (CVM). The results of this study are that the majority of respondent's report WTP for marine conservation, where the probability of paying respondents is $93.2 \%$ and $92.3 \%$. In addition, there are significant differences in factors that affect an individual's willingness to pay and the amount of payment. The amount of payment is significantly affected by demographic characteristics, such as income, gender, education, age, and other sociodemographic characteristics. In addition, the frequency of visits affects WTP (Song, Lv, \& Lee, 2015). Age, education, and income affect the willingness to pay (Samdin, Abdul Aziz, Radam, \& Yacob, 2010; Pantari, 2016).

In a study conducted by Jala and Nandagiri (2015), it was found that the level of education, sex and housing status influence the value of willingness to pay for additional facilities. Whereas personal and demographic variables such as age, income, gender, education and housing status affect the average willingness to pay of visitors for recreational benefits according to the Travel Cost Method (TCM). Days spent and travel expenses have a positive and significant relationship with WTP (Mohanthy, 2014). 
Variables such as travel costs, travel time, education and age are effective variables that indicate the number of visitors (Mohammadi Limaei, Ghesmati, Rashidi, \& Yamini, 2014).

Other research related to the analysis of WTP in Semarang City by Rahmawati and Sasana (2014) shows that the perception of natural beauty, income, education has a positive and significant effect on the amount of value that visitors are willing to pay. Distance and frequency of visits negatively affect the value of WTP that are willing to be paid by visitors (Pantari, 2016). According to Sari (2017) age has a negative and significant influence on visitor Willingness to Pay. This is due to the average visitor being in their teens and as they get older, the level of activity will also increase and also as someone ages, the physical strength to conduct tourism activities will decrease, so that the willingness to pay will be even smaller. The level of education and income has a positive and significant effect on Willingness to Pay. And distance does not have a significant effect on Willingness to Pay visitors. The relationship of independent variables with previous research can be seen in the following Table 1.

Table 1 Relationship of independent variables

\begin{tabular}{lcl}
\hline Independent Variables & Relation & \multicolumn{1}{c}{ References } \\
\hline Age & + & Criddle (2014), Gaviria \& Martinez (2014), Mohammadi \\
& & $\begin{array}{l}\text { Limaei et al. (2014), Mohanthy (2014), Samdin et al. } \\
\text { (2010), Pantari(2016), Sari (2017), Yu et al. (2018). }\end{array}$ \\
Education & + & $\begin{array}{l}\text { Adekunle (2012), Jala and Nandagiri (2015), } \\
\text { Mohammadi Limaei et al. (2014), Samdin et al. (2010), }\end{array}$ \\
& & $\begin{array}{l}\text { Saptutyningsih \& Selviana (2017), Sari (2017), Yu et al. } \\
\text { (2018). }\end{array}$ \\
Income & + & $\begin{array}{l}\text { Adekunle (2012), El- Bekkay (2013), Pantari (2016), } \\
\text { Putri et al. (2017), Samdin et al. (2010), Sari (2017), }\end{array}$ \\
Frequency of visits & & Saptutyningsih \& Selviana (2017), Yu et al. (2018). \\
Visitor perception & - & Pantari (2016), Prasetyo \& Saptutyningsih (2013). \\
Distance & + & Mohammed et al. (2013), Rahmawati \& Sasana (2014). \\
\hline
\end{tabular}

\section{Research Method}

The study was carried out in the Liwa Botanic Garden tourist object and the research topics were visitors to the Liwa Botanic Garden attraction from March 05-April 4, 2019. This study uses primary data types collected through direct interviews of research subjects, tourists who come to the attraction of the Liwa Botanical Garden as respondents. The purposeful sampling of all the test samples is done. This approach utilizes parameters chosen in the study by the researchers. In this process there are two sample requirements, the first being that inclusion is the ideal criterion researchers want based on the research goals. Second, exclusion is a specific criterion that causes prospective respondents to be excluded from the research respondent group which fits the criteria. The inclusion criteria for this study alone were respondents who were visitors to the Liwa Botanical Garden attraction with the requirements of respondents aged 20 years and older, and who were already working. Although the exclusion criteria 
were Liwa Botanical Garden respondents who were aged twenty years and over but did not work. The sample size for this analysis was calculated using the formula:

$$
s=\frac{\lambda^{2} \cdot N \cdot P Q}{d^{2}(N-1)+\lambda^{2} \cdot P \cdot Q}
$$

It is known that $\lambda^{2}$ with $\mathrm{dk}$ is equal to 1 with an error level of $5 \%, P=Q .5, d=0.05, \mathrm{~N}$ is the number of tourists visiting the Liwa Botanical Garden in 2017/2018, and $s$ is the number of samples. By estimating that the relationship between variables is a fairly close relationship, then by using a sample table developed by Isaac and Michael (Andrianty, et al, 2012) obtained samples in this study were 304 people.

Binary logistic regression is a method of evaluating the relationship between response variables $(\mathrm{y})$ and binding variables $(\mathrm{x})$ with dichotomous or polycotomous properties (Hosmer and Lemeshow, 1989). The answer variable results are divided into two choices, namely the response "yes" and "no" where each choice has a different value for yes $=1$ and no $=0$. Basically this binary logistic analysis is the same as multi-regression analysis, which distinguishes both binary dependent variables which are dummy variables ( 0 and 1$)$. There are no classical assumptions in binary logistics analysis, such as multiple regression. The regression model in this study functions as follows, based on empirical studies:

$$
\log \left(\frac{p}{1-p}\right)=\beta 0+\beta 1 \text { Age }+\beta 2 E d u+\beta 3 \text { Inc }+\beta 4 J r+\beta 5 \text { Frek }+\beta 6 \text { Presep }+\mathrm{e}
$$

\begin{tabular}{|c|c|}
\hline Variables & Definitions \\
\hline \multicolumn{2}{|r|}{ Dependent variable } \\
\hline WTP tourist attraction & $\begin{array}{l}\text { Willingness To Pay (WTP) is a willingness to pay visitors to } \\
\text { Liwa Botanical Garden attraction which is stated in } \\
\text { rupiah (Rp). The dummy variable value for WTP is } 1 \text { if } \\
\text { "WTP = EWTP" and 0 if "WTP } \neq \text { EWTP" }\end{array}$ \\
\hline \multicolumn{2}{|r|}{ Independent variable } \\
\hline Education & $\begin{array}{l}\text { Judging from the last level of education that has been taken by } \\
\text { respondents such as SD, SMP, SMA and college }\end{array}$ \\
\hline Age & $\begin{array}{l}\text { The age level of visitors and measured in ratio with units of } \\
\text { the year. In the age variable has an age limit that is more } \\
\text { than } 20 \text { years }\end{array}$ \\
\hline Income & $\begin{array}{l}\text { Net income from all work carried out by respondents both } \\
\text { primary work and side work within a month }\end{array}$ \\
\hline Distance & $\begin{array}{l}\text { Distance from the visitor's home to get to the Attraction. This } \\
\text { variable is measured in kilometers }(\mathrm{Km})\end{array}$ \\
\hline Frequency of visits & $\begin{array}{l}\text { How often did respondents come to or how many times they } \\
\text { visited a tourist attraction in the past year }\end{array}$ \\
\hline Visitor perception & $\begin{array}{l}\text { This perception is shown by the level of visitor satisfaction } \\
\text { with a particular tourist attraction. Dummy perception, } \\
\text { which is } 1 \text { if satisfied; } 0 \text { if not }\end{array}$ \\
\hline
\end{tabular}

Table $\mathbf{2}$ The difinition of explanatory variables 


\section{Result and Discussion}

This study was conducted among 304 respondents who visited the Liwa Botanical Garden attraction, as many as $68 \%$ of visitors who came were aged 20-30 years with $48 \%$ of respondents having an average or equivalent high school education. Most of the visitors to the Liwa Botanical Garden have visited more than 3 times with a total percentage of $37 \%$. However, most respondents thought the road to the Liwa Botanical Garden was in good condition, had full facilities and a clean tourist attraction. So $85 \%$ or 257 respondents were satisfy to visit the Liwa Botanical Garden attraction.

Willingness to pay the attractions for the development and preservation of Liwa Botanic Garden is an analysis of how much willingness to pay user entry fees for the development and preservation of the Liwa Botanic Garden attractions. The fee for the Willingness to Pay levy accessing the tourist attraction in this case is Rp6.500,00. Of the 304 respondents, $88 \%$ are willing to pay entry fees for the growth and protection of the tourist attraction Liwa Botanical Garden. Based on the results of research related to the development of the Liwa Botanical Garden tourist attraction's willingness to pay (WTP) and environmental conservation, the results of the descriptive study can be seen in the following Table 3.

Table 3 Variable Descriptive Statistics

\begin{tabular}{lllll}
\hline & Min & Max & Mean & Std. Deviation \\
\hline Willingness to pay (WTP) & 0 & 1 & 0.88 & 0.331 \\
Age (Age) & 20 & 61 & 29.04 & 8.485 \\
Education (Edu) & 0 & 16 & 11.65 & 3.057 \\
Income (Inc) & 500000 & 15000000 & 2066447.37 & 1286971.736 \\
Frequency of visits (Frek) & 1 & 350 & 5.23 & 20.276 \\
Distance (Jr) & 1 & 200 & 36.42 & 34.136 \\
Visitor Perception (Persep) & 0 & 1 & 0.66 & 0.475 \\
\hline
\end{tabular}

Table 3 indicates the lowest amount of willingness to pay is 0 and the highest value of willingness to pay element is 1 . The average value of the willingness to pay variable is 0,88 which means that the variable willingness to pay is dominated by respondents willing to pay as much as Rp6.500,00 to establish and maintain Liwa Botanical Garden attractions. The lowest income variable is Rp500.000,00 and the highest income variable value is $\mathrm{Rp} 15.000 .000,00$. The average income variable value is $\mathrm{Rp2} .066 .447,37$ which states that the income variable is dominated by respondents earning approximately Rp1.000.000,00-Rp2.000.000,00 per month. The minimum value for the variable distance is $1 \mathrm{~km}$, and the maximum value for the variable distance is $200 \mathrm{~km}$. For the average distance variable value is $36,42 \mathrm{~km}$ where tourists are driven by respondents whose residence is around $30 \mathrm{~km}-40 \mathrm{~km}$ to the tourist attraction.

The results of the visit frequency variable analysis with the lowest value is 1 and the maximum value is 350 . For the average value of the visit frequency variable is $5,23,304$ respondents who visited were dominated by visitors who visited 5 to 10 times in the last year can be concluded. Next on the perception variable the lowest value is 0 , and the 
highest value is 1 . The average perception variable value of 0.66 can be said to have satisfied most respondents visit the Liwa Botanical Garden attraction.

On the age variable the lowest value is 20 years and the highest value is 61 . For the average age value is 29,04 , which means the age variable is predominantly $20-30$ years old. Therefore, the lowest educational level is 0 or has not finished elementary school and the highest rating is 16 years. The average educational value of the variable is 11.65 , indicating that the average respondent is educated for 9-12 years.

Negelkerke R Square test results of 0,204 or $20,4 \%$ showing that the dependent variable can be clarified in this $20,4 \%$ study model by the independent variables. While the remainder is 0,796 or $79,6 \%$, outside this analysis is clarified.

On the basis of Homser and Lameshow testing it can be seen that the Chi-square value of 6,729 with a meaning probability value of 0,566 >0,05 can be said to be fit and able to predict its observation value so that it can be concluded that the regression used in this study is appropriate for further analysis.

Table 4 Regression result

\begin{tabular}{|c|c|c|c|}
\hline Variables & $\mathrm{B}$ & Wald & $\operatorname{Exp}(B)$ \\
\hline Age & $\begin{array}{l}0.074 \\
(0.038)\end{array}$ & 3.886 & $1.077 * *$ \\
\hline Edu & $\begin{array}{l}0.153 \\
(0.73)\end{array}$ & 4.367 & $1.165 * *$ \\
\hline Inc & $\begin{array}{l}0.000 \\
(0.000)\end{array}$ & 3.981 & $1.000 * *$ \\
\hline Frek & $\begin{array}{l}0.103 \\
(0.064)\end{array}$ & 2.586 & 1.108 \\
\hline $\mathrm{Jr}$ & $\begin{array}{l}-0.005 \\
(0.006)\end{array}$ & 0.755 & 0.995 \\
\hline Persep & $\begin{array}{l}-1.080 \\
(0.470)\end{array}$ & 5.290 & $0.339 * *$ \\
\hline Constant & $\begin{array}{l}-2.300 \\
(1.466)\end{array}$ & 2.461 & 0.100 \\
\hline
\end{tabular}

Explanation : Dependent variable : Dummy WTP; ( ) shows the standard coefficient of Error; ${ }^{*}$ Significance at $(\alpha=10 \%) ;{ }^{* *}$ Significance at $(\alpha=5 \%) ; * *$ Significance at $(\alpha=$ $1 \%)$.

Based on the results of the study the age variable has a probability of 0.049 , smaller than 0.05 can be interpreted that the age variable has a significant influence on Willingness to Pay with the coefficient value showing a positive sign (+). Odds ratio for the age variable is 1.077 . The results of the study of age variables statistically have a significant influence on the value of willingness to pay for the development and preservation of the tourism object Liwa Botanical Garden, It means that as a person's age increases and the task becomes more hectic a person may feel tired and bored and need exercise or travel, in this case a high age does not affect the interest in traveling. The age variable coefficient value is positive, meaning that getting older will increase awareness of preserving the environment and increase awareness of the potential for 
tourism artifacts to be preserved. That is the reason why age has a positive effect on the value of willingness to pay (Yu et al., 2018; Pantari, 2016; Sari, 2017; Mohammadi Limaei et al., 2014).

The education variable has a probability of 0.037 , smaller than 0.05 which means that education has a significant influence on the Willingness to Pay of visitors in efforts to develop and preserve the attractions of Liwa Botanical Garden. Odds ratio value of the education variable is 1.165 with a coefficient marked positive. When the educational level of the respondent is higher, the willingness to be willing to pay rises. This is because the higher the education, the greater the individual's awareness and knowledge of the benefits of maintaining environmental quality. Higher education will build a more critical thinking regarding efforts to preserve the environment by understanding the effects that will be accomplished if it affects the environment, so that environmental conditions can be preserved and changed for the better (Yu et al., 2018; Saptutyningsih \& Selviana, 2017; Adekunle, 2012; Jala \& Nandagiri, 2015).

The results of this study also obtained the results of income variables that had a significant and positive effect on Willingness to Pay for the development and preservation of the environment. Odds ratio value of income variable is 1,000 . The income variable is very influential on the WTP because if the respondent's income increases, the chances of the respondent to pay increases as well, because the high income will make tourists have more funds to pay. Moreover, when a person's income increases, the desire to travel will increase so that they can encourage someone to set aside their money to improve the quality of a tourist attraction's environment so that when they return to visit the environment and facilities around the tourist attraction they will increase for the better (Putri et al. 2017; Pantari, 2016; Mohammaed et al., 2013).

Based on the results of research that has been conducted statistically the frequency of visits does not have a significant effect but has a positive coefficient on visitors' willingness to pay in efforts to improve and preserve the environment of the Liwa Botanical Garden. These results are in accordance with research conducted by Prasetyo and Saptutyningsih (2013), and Pantari (2016). The coefficient of visit frequency results shows a positive value, this is because the higher the frequency of respondents' visits to tourism, the greater the willingness to pay given because visitors can know the development of the tourist attraction. This attribute has no significant influence because tourists from outside the tourist attraction dominate the average visitor of the Liwa Botanical Garden attraction and has only recently visited the Liwa Botanical Garden attraction. This work is not in line with the research conducted by Rahmawati and Sasana (2014) and Song, et al (2015), because what is happening now is that the Liwa Botanical Garden is still relatively new, so tourists prefer not previously visited attractions because they will have a separate attraction for visitors.

The results of the analysis on distance variables where distance does not have a significant effect on the willingness to pay of visitors to the Liwa Botanical Garden attraction. This is because the urge to travel occurs when someone is disturbed by the 
surrounding environment so that they want to see a beauty that is only possible at a specific tourist attraction, besides that, from the field survey respondents who already have children would take the time to drive when they are on vacation, even if the distance is far enough so that more crowded tourists from outside the region are on vacation. The aim of a tour is to refresh the mind and self so that when someone travels a great distance to reach a tourist attraction it does not become an obstacle (Sari, 2017). According to Rahmawati and Sasana (2014) distance significantly influences visitor's Willingness to Pay value.

Research that has been done on the visitor perception variable shows that the perception has a significant effect but has a negative coefficient on the willingness to pay of the tourist attraction. In this case visitors with unhappy perceptions of Liwa Botanical Garden attractions tend to be willing to pay more. This is because visitors believe that when they return to the Liwa Botanical Garden attractions they will see many improvements and innovations that are better than before. Therefore, on average, visitors want the manager to install more facilities and increase plant types because they are considered to be of a relatively small nature. This research is inversely proportional to the previous research conducted by Sari (2017) and Rahmawati and Sasana (2014) in their research that the perception variable does not have a significant effect on visitor willingness to pay.

\section{Conclusion}

The average value of willingness to pay (EWTP) in this study was Rp6.500,00. A total of 266 respondents were willing to pay retribution to enter the attractions of Liwa Botanic Garden and 38 respondents were not willing to pay fees to enter the attractions of Liwa Botanic Gardens. The age level has a positive and significant influence on the willingness to pay of visitors to the Liwa Botanical Garden attraction. The manager of the Liwa Botanical Garden can use this to add facilities such as seating or gazebo, because older visitors prefer to relax and enjoy the view. Meanwhile, education has a statistically significant effect and is positively related to the willingness to pay of visitors to the effort to develop and preserve the attractions of Liwa Botanical Garden. The higher the education, the greater the understanding and knowledge of the benefits of maintaining environmental quality. Higher education will create a more advanced environmental sustainability thinking by knowing the impacts that will be obtained if it damages the environment, in order to bring about a better environmental change, especially for the environment.

Income has a positive and significant impact on Willingness To Pay for the development and preservation of the environment. Income variable is very influential on WTP because income will make tourists have funds to pay moreTherefore, when a person's income increases, the urge to travel increases, and this also significantly encourages someone to set aside their money to improve the quality of a tourist attraction's atmosphere so that when they return to visit a tourist attraction there is an increase. 
Perception has a significant effect but negatively impacts the willingness to pay of visitors to attractions. In this case, visitors with dissatisfied perceptions of the attractions of the Liwa Botanical Garden have an impact on the value of willingness to pay is low. This happens because tourists give willingness to pay based on satisfaction with the facilities and the beauty of the plants.

\section{References}

Adekunle, M. F. (2012). Public willingness to pay for ecosystem service functions of a periurban forest near Abeokuta, Ogun State, Nigeria. Journal of Development and Agricultural Economics, 4(2), 45-50. https://doi.org/10.5897/jdae11.085

Badan Pusat Statistik. (2018). Lampung Barat Dalam Angka 2018. Lampung Barat: Badan Pusat Statistik Lampung Barat.

Badan Pusat Statistik. (2018). Provinsi Lampung Dalam Angka Tahun 2018. Lampung: Badan Pusat Statistik Lampung.

Fauzi, A., (2010). Ekonomi sumberdaya alam dan lingkungan teori dan aplikasi. Jakarta: Gramedia Pustaka Utama.

Gaviria, C., \& Martínez, D. (2014). Air pollution and the willingness to pay of exposed individuals in downtown medellín, Colombia. Lecturas de Economía, 80, 153-182. https://doi.org/10.17533/udea.le.n80a6

Jala, \& Nandagiri, L. (2015). Evaluation of economic value of pilikula lake using travel cost and contingent valuation methods. Aquatic Procedia, 4, 1315-1321.

Mohammadi Limaei, S., Ghesmati, H., Rashidi, R., \& Yamini, N. (2014). Economic evaluation of natural forest park using the travel cost method (case study; Masouleh forest park, north of Iran). Journal of Forest Science, 60(No. 6), 254-261. https://doi.org/10.17221/84/2013-jfs

Mohammed, E. B., Abedellatif, M., \& Faiccedil al, B. (2013). An economic assessment of the Ramsar site of Massa (Morocco) with travel cost and contingent valuation methods. African Journal of Environmental Science and Technology, 7(6), 441-447. https://doi.org/10.5897/ajest2013.1485

Mohanthy, B. d., 2014. Determination of Willingness to Pay for Entrance fee to National Park. An Empirical Investigation, pp. Jurnal Volume. 35, Issue No. 4.

Prasetyo, N., \& Saptutyningsih, E. (2013). Bagaimana kesediaan untuk membayar peningkatan kualitas lingkungan desa wisata?. Jurnal Ekonomi \& Studi Pembangunan, 14(2), 127-136. Retrieved from

https://journal.umy.ac.id/index.php/esp/article/view/1259

Putri, D. K., Subiyanto, S, \& Awaludin, M. (2017). Analisis nilai willingness to pay dan travel cost untuk pembuatan peta zona nilai ekonomi kawasan pantai marina dan puri maerokoco Semarang menggunakan sistem informasi geografis (SIG). Jurnal Geodesi Undip, 6(3), 47-56. Retrieved from https:// ejournal3.undip.ac.id/index.php/geodesi/article/view/17187

Rahmawati, C. \& Sasana, H., (2014). Anlisis willingness to pay wisata air sungai pleret kota Semarang. Doctoral dissertation, Fakultas Ekonomika dan Bisnis, Universitas Diponegoro.

Samdin, Z., Abdul Aziz, Y., Radam, A., \& Yacob, M. R. (2010). Factors Influencing the Willingness to Pay for Entrance Permit: The Evidence from Taman Negara National Park. Journal of Sustainable Development, 3(3), 1-9.

https://doi.org/10.5539/isd.v3n3p212 
Saptutyningsih, E., \& Selviana, R. (2017). Valuing Ecotourism of a Recreational Site in Ciamis District of West Java, Indonesia. JEJAK, 10(1), 172-188. https://doi.org/10.15294/jejak.v10i1.9134

Sari, K. L., 2017. Faktor-faktor yang mempengaruhi willingness to pay pengunjung objek wisata Umbul Ponggok. Skripsi Universitas Muhammadiyah Yogyakarta.

Song, X., Lv, X., \& Li, C. (2015). Willingness and motivation of residents to pay for conservation of urban green spaces in Jinan, China. Acta Ecologica Sinica, 35(4), 89-94. https://doi.org/10.1016/j.chnaes.2015.06.003

Spillane, J. J., (1991). Ekonomi pariwisata, sejarah dan prospeknya. Yogyakarta: Kanisius. Yakin, A., (1997). Ekonomi sumber daya dan lingkungan. Jakarta: Akademi Presindo.

Yu, B., Cai, Y., Jin, L., \& Du, B. (2018). Effects on Willingness to Pay for Marine Conservation: Evidence from Zhejiang Province, China. Sustainability, 10(7), 2298. $\underline{\text { https://doi.org/10.3390/su10072298 }}$ 